\title{
STUDY ON LIVER ARSENIC LEVEL IN ANTIBIOTIC TREATED RATS
}

\author{
CHOUDHRY ZK ${ }^{1}$, AFRIN M² ${ }^{2}$ SALEH AA ${ }^{3}$, MOJLISH UKF ${ }^{4}$
}

\begin{abstract}
Rats treated with arsenic $(1 \mathrm{mg} / \mathrm{L})$ in drinking ad libitum an increase in liver tissue arsenic was observed when orally pretreated with streptomycin (500mg twice daily). Inhibition of gut flora was confirmed by microscopic examination of stool. Control group showed a mean gut-bacterial count of $7.13-7.26 \times 10^{8} \mathrm{cfu} / \mathrm{g}$ dry weight of stool, when administered with streptomycin orally (500mg twice daily) gut-bacterial count was not countable on day 7. Liver tissue arsenic level increased to $5.78 \mathrm{mg} / \mathrm{g}$ of liver tissue compared to that of the control group of $3.33 \mathrm{mg} / \mathrm{g}$ of liver tissue. A decrease in gut-bacterial count of $2.83 \times 10^{8} \mathrm{cfu} / \mathrm{g}$ dry weight of stool was observed on day 14 in rats that were not pretreated with streptomycin but received only arsenic $(1 \mathrm{mg} / \mathrm{L})$ in drinking water ad libitum throughout the study period. Increase in liver arsenic level in this group was almost similar to that of streptomycin pretreated rats.
\end{abstract}

Key words: Arsenicosis, Liver arsenic level, Antibiotic, Streptomycin, Long Norwegian rat.

J Dhaka Med Coll. 2013; 22(1) : 51-54.

\section{Introduction}

Arsenicosis is a major health hazard in an underdeveloped country like Bangladesh. Environmental pollution of arsenic is from industrial sources, use of wood preservatives, metallurgical, mining and use of insecticides. ${ }^{1}$ Significantly high level of arsenic in ground water has been observed in some areas of Bangladesh. Maximum safe permissible limit of arsenic in water by WHO is $0.01 \mathrm{mg} / \mathrm{L}$. In many areas of Bangladesh, particularly along the Ganges, Brahmaputra, Delta it is above the safe drinking standard. ${ }^{5}$

Water contaminated with arsenic is used for purpose of irrigation has led to its redistribution in food stuff. ${ }^{2}$ Use of organic arsenicals like roxersone in poultry feed, as an intestinal palliative and to increase growth has also led to its distribution in food stuff. ${ }^{2}$ Antibiotics now a days are being used by practitioners at all levels most of the time without proper indication. Irrational and improper use of such antibiotics might have an adverse effect, leading to inhibition of gut flora. $^{3,4}$
Gut flora are considered to be bodies first line of defence mechanism against ingested xenobiotics. So indiscriminate and improper use of antibiotics in areas where people are chronically exposed to arsenic through drinking water can result in permanent and severe damage to human health, including lesions of skin $^{1}$, mucous membrane, digestive tract $^{2}$ and damage to respiratory ${ }^{3}$, circulatory ${ }^{4}$, endocrine $^{5}$ and nervous system. ${ }^{6}$ Arsenic is a documented human carcinogen associated with skin, liver and lung cancers and has been classified by WHO's International Agency for Research on Cancer into Group-I. Epidemiological studies suggest that persons with impaired arsenic metabolism are at increased risk of arsenicosis. Detoxification of arsenic takes place both in liver and by gut flora. ${ }^{9}$ Hepatic methylation of arsenic is being challenged as growing number of reports of studies in experimental model system indicate that hepatic methylation of arsenic is more toxic than methylation by gut flora. ${ }^{18}$ This study was carried out with a view to see the inhibitory effect of antibiotics and gut flora and its effect on hepatic methylation of arsenic.

1. Dr. Zubaida Khatoon Choudhry, Department of Pharmacology, MARKS Medical College, Mirpur, Dhaka.

2. Dr. Munira Afrin, Department of Pharmacology, International Medical College, Tongi, Gazipur.

3. Dr. Ahmed Abu Saleh, Department of Microbiology \& Immunology, Bangabandhu Sheikh Mujib Medical University (BSMMU), Dhaka.

4. Dr. UKF Mojlish, Department of Biochemistry, International Medical College, Tongi, Gazipur.

Correspondence : Dr. Zubaida Khatoon Choudhry, Department of Pharmacology, MARKS Medical College, Mirpur, Dhaka 


\section{Materials and Methods}

Animals: Healthy young adult male rats of Long Norwegian Strains, weighing 160-180g and 34 months old were taken for the purpose of study. They were kept in stainless steel cages in animal house. Saw dust was used as beding and changed every alnernate day, a 12 hours light/ 12 hours dark cycle was maintained. They were fed standared pellet diets and allowed to drink ad libitum.

A total of 24 rats were used in this study and divided into four groups. Group A was control, Group B received only streptomycin (500mgm twice daily) orally, group $\mathrm{C}$ received only arsenic (1mg/L) and group D received arsenic with streptomycin orally for 14 days. Stool was cultured in MacConkey's agar and complete inhibition of gut flora was ensured by microscopic examination of stool.
Stool specimen collection, dilution and culture: Fecal pellets were collected in clean, sterile glass container as soon as they were passed by the animal. A portion of fresh stool specimen was taken in sterile labelled test tubes containing $1 \mathrm{ml}$ of normal saline, vortexed and centrifuged at $1600 \mathrm{~g}$. The supernatant was decanted and serial dilution (1-5) was carried out in sterile test tubes containing $1 \mathrm{ml}$ of normal saline. From the fifth test tube $10 \mu 1$ of specimen was taken and cultured in MacConkey's agar at $37^{\circ} \mathrm{C}$ for 24 hours, for colony count. Stool cultures were performed on day 0 , day 7 and day 14 of administering drugs.

\section{Liver and stool arsenic estimation:}

Remaining portion of stool was estimated for arsenic. Animals were sacrificed on day fourteen under light chloroform anaesthesia. Liver taken out and arsenic estimation done. Both stool and liver arsenic were estimated by SDDC method (silver diethyldithiocarbamate method).

\section{Results}

Table I

Inhibilion of gut flora

\begin{tabular}{lccr}
\hline Groups & \multicolumn{3}{c}{ Bacterial Count (cfu/g dry weight of stool) } \\
\cline { 2 - 4 } & $7.13 \times 10^{3} \pm$ & Day 7 & Day 14 \\
\hline Control & $0.49 \times 10^{3}$ & $\pm .19 \times 10^{3}$ & $7.26 \times 10^{3}$ \\
& $7.08 \times 10^{3} \pm$ & Not Countable & $\pm 0.06 \times 10^{3}$ \\
Only streptomycin (1g/Day) & $0.54 \times 10^{3}$ & & Not Countable \\
& $7.01 \times 10^{3} \pm$ & $7.74 \times 10^{3}$ & \\
Only Arsenic (1mg/L) & $0.56 \times 10^{3}$ & $\pm 1.33 \times 10^{3}$ & $2.83 \times 10^{3}$ \\
& $7.01 \times 10^{3} \pm$ & Not Countable & Not Countable \\
Arsenic (1mg/L) + & $0.56 \times 10^{3}$ & & \\
streptomycin (1g/Day) & &
\end{tabular}

All valuable result are presented as mean $\pm \mathrm{SD}$ and Statistically significant $\mathrm{P}$ value is $>0.05$

Table II

Stool \& Liver arsenic concentration

\begin{tabular}{|c|c|c|c|c|}
\hline \multirow[t]{2}{*}{ Groups } & \multicolumn{2}{|c|}{ Stool mg/g dry weight } & \multicolumn{2}{|c|}{ Liver tissue $\mathrm{mg} / \mathrm{g}$} \\
\hline & Day 0 & Day 7 & Day 14 & Day 14 \\
\hline Control & $3.38 \pm 0.63$ & $3.74 \pm 0.67$ & $3.63 \pm 0.79$ & $3.33 \pm 0.92$ \\
\hline Only streptomycin (1g/Day) & $3.56 \pm 0.34$ & $3.31 \pm 0.52$ & $3.72 \pm 0.67$ & $3.63 \pm 0.21$ \\
\hline Only Arsenic (1mg/L) & $3.33 \pm 0.68$ & $3.31 \pm 0.72$ & $2.39 \pm 0.27$ & $5.40 \pm 0.71$ \\
\hline $\begin{array}{l}\text { Arsenic }(1 \mathrm{mg} / \mathrm{L})+\text { streptomycin } \\
(1 \mathrm{~g} / \text { Day })\end{array}$ & $3.43 \pm 0.36$ & $2.58 \pm 0.24$ & $2.52 \pm 0.27$ & $5.78 \pm 0.46$ \\
\hline
\end{tabular}

All valuable result are presented as mean $\pm \mathrm{SD}$ and Statistically significant $\mathrm{P}$ value is $>0.05$ 
The mean gut bacterial count in control group was 7.13 to $7.26 \times 10^{8} \mathrm{cfu} / \mathrm{g}$ dry weight of stool (Table I). Oral administration of streptomycin caused a reduction in gut bacterial count to not countable level on day 7 and day 14. Rats treated only with arsenic also showed an inhibition of gut flora from $7.01 \times 10^{8} \mathrm{cfu} / \mathrm{g}$ dry weight stool to $2.83 \times 10^{8} \mathrm{cfu} / \mathrm{g}$ dry weight of stool, here gut flora reduced significantly but did not go to uncountable levels. So it was observed that both streptomycin and arsenic inhibit gut flora but rate of inhibition of streptomycin was more than that of arsenic, being almost 100\% incase of streptomycin treated rats. Mean stool arsenic level in control group ranged from $3.38-3.63 \mathrm{mg} / \mathrm{g}$ dry weight of stool (Table II). It decreased significantly on day 14 to $2.52 \mathrm{mg} / \mathrm{g}$ dry weight of stool in rats that received streptomycin with arsenic and $2.39 \mathrm{mg} / \mathrm{g}$ dry weight of stool in rats that received only arsenic.Liver arsenic level in control groups of rats was $3.33 \mathrm{mg} / \mathrm{g}$ of liver tissue (Table II). An increase in liver arsenic level was observed in groups that received arsenic with streptomycin $5.78 \mathrm{mg} / \mathrm{g}$ of liver tissue and only arsenic $5.90 \mathrm{mg} / \mathrm{g}$ of liver tissue. In streptomycin treated group liver arsenic level increased to $5.78 \mathrm{mg} / \mathrm{g}$ of liver tissue an increase of $62.16 \%$ compared to control group.

\section{Discussion}

Inhibition of gut bacteria by streptomycin and subsequent administration of arsenic, caused a significant increase in liver tissue arsenic level. Liver tissue arsenic level also increased in rats that received only arsenic. Increase in streptomycin treated group was more than in untreated group. Inhibitation of gut bacteria was also observed and was more marked in strepto-mycin treated rats, where it decreased to uncountable levels uggesting an important role of gut bacteria in arsenic metabolism.

Gut bacteria play an important role in metabolic, tropic and protective functions and play a vital role in bodies immunity. ${ }^{10}$ Several studies carried out in this aspect show that bacteria play an important role in arsenic detoxification. ${ }^{11,13}$ Liver is an important organ of arsenic detoxification, but this concept has been challenged now as growing number of reports of studies in experimental model system indicate that hepatic methylation of arsenic is more toxic than methylation by gut flora. ${ }^{18}$ More stress is being given to detoxification by gut flora.Arsenic detoxification in liver results in formation of MMA III and DMA III which are more toxic than any inorganic arsenic or any other pentavalent intermediates. ${ }^{12}$ Gut flora produce MMMV and DMV which are non toxic and finally TMA III in gaseous form. ${ }^{9}$ Besides arsenic microbes have been found to reduce a wide range of toxic metals through detoxification and elimination. ${ }^{14}$ Which suggests an important role of gut bacteria in bodies defence mechanism.

In this study inhibition of gut bacteria in rats by oral streptomycin and subsequent administration of arsenic showed a significant increase in liver arsenic level, it was also observed that chronic exposure to arsenic also had an inhibitory effect on gut bacteria andincrease in liver arsenic level. Increase in liver arsenic level streptomycin treated group was more, it could be concluded that inhibition of gut flora results in increase entry of arsenic inside the body. Exposure to arsenic results in formation of reactive oxygen species ( ROS) and reactive nitrogen species (RNS) which are directly involved in oxidative damage to lipids, proteins and DNA in cells exposed to arsenic. ${ }^{15}$ It plays a role in blackfoot disease, Diabetes mellitus, ${ }^{16}$ gastrointestinal, neurological and cardiovascular diseases. ${ }^{6}$

People in Bangladesh are exposed to arsenic throughfood ${ }^{2}$ and drinking water, ${ }^{5}$ inhibitory effect of arsenic in gut flora and increased liver concentration of arsenic requires proper and rational use of antibiotics. Irrational use of antibiotics might lead to inhibition of gut flora and increase the risk of arsenacosis, particularly in arsenic exposed areas leading to increased incidence of systemic diseases, which not only increases morbidity and mortality but also puts a heavy pressure on the countries economy.

Maintenance of healthy gut bacteria is very important to maintain good health. It has been 
observed that environmental and nutritional factors play a major role in determining the extent and type of colonization by gut bacteria. ${ }^{18}$ Use of probiotics i.e foods which contain live bacteria beneficial to health and prebiotics i.e foods which contain certain non digestable oligosaccharides which selectively stimulate the growth of bifidobacteria in the colon ${ }^{19}$ along with judicious use of antibiotics is advocated to prevent or cure infections, disease and perhaps immunopathologic disorders.

\section{Acknowledgement}

Special thanks to Prof. Md. Ruhul Amin Miah, Department of Microbiology, Bangabandhu Sheikh Mujib Medical University, Dhaka, for his kind co-operation.

\section{References}

1. French DK. Arsenic in the environment. Environ Sci 2005; 182: 1-7.

2. Oremland RS. Arsenic eating bacteria rewrite evolutionary history. New Scientist Tech 2008; 12: $45-60$.

3. Choudhry ZK, Misbahuddin M, Hosain AK, Saleh AA. Inhibitory effect of arsenic on aerobic gut flora in rat. Bangladesh Med Res Counc Bull 2009; 35(3): 79-83.

4. Upretic RK, Shivastava R, Chaturvedi CU. Gut microflora and toxic metals: chromium as a model. Indian J Med Res 2004; 119: 49-50.

5. Haque AAM, Thwe HM, Jayasuraia HPW, Hossain MZ, Rahman M, Rashid HU. Ground water arsenic contamination, food safety and human health hazards in Bangladesh. CMU J Nat Sci 2007;6: 321-39.

6. Engel RR, Smith AH. Arsenic in drinking water and mortality from vascular disease, and ecologic analysis in 30 countries in the United States Ach Environ Health 1994; 49: 418-27.

7. Wang W, Linsheng Y, Shaofan H, Jiannan T, Hairong L. Prevention of endemic arsenism with selenium. Current Science 2001; 81: 1215-8.

8. Styblo M, Yamauchi H, Thamas DJ. Comparative methylation of trivalent and pentavalent arsenicals. Toxicol Appl Pharmacol 1995; 135: 172-8.

9. Cerventes C. Bacterial resistance to arsenic compounds. Microbiol 1995; 37: 387-95.

10. Guarner F, Malagelada JR. Gut flora in health and disease. Lancet 2003; 360: 512-9.

11. Rowland IR, Davies MJ. In vitro metabolism of inorganic arsenic by gastro intestinal microflora of the rat. J Appl Toxicol 1981; 1: 278-82.

12. Gamble MV, Liu X, Ahasan H, Rich J, Lievski V, Salvkovich V, et al. Folatehomocystine and arsenic metabolism exposed individuals in Bangladesh. Environ Health Perspect 2005; 113: 1683-8.

13. Qin J, Rosen BP, Zhang Y, Wang G, Frankie S, Rensing C. Arsenic detoxification and evolution of trymethyl arsenic gas by a microbial arsenite S-adenosyl methionine methyltransferase. PANS 2006; 103: 2075-80.

14. Upreti RK, Kannan A, Shrivastava R, Chaturvedi CU. A comparative study on rat intestinal epithelial cells and resident gut bacteria: effect of arsenite. Biol Med Environen Sci 2006; 19: 77-86.

15. Roy P, Saha A. Metaboloismana toxicity of arsenic. A human carcinogen. Curren Sci 2002; 82: 38-45.

16. Tseng CH, Tui TY, Cheng CK, Tseng CP, Lai MS, Chiou HY, et al. Long term arsenic exposure and incidence of non insulin dependent diabetes mellitus: a cohort study in arseniasis hyperendemic villages in Taiwan. Environ Health Perspect 2000; 108: 1-10.

17. Kulp RT, Hoeft ES, Asao M, Madigan TM, Hollibaugh TJ, Fisher CJ, et al. Arsenic III fuels anoxgenic photosynthesis in hot spring biofilms from monolake California. Science 2008; 321 : 967-70.

18. Ahsan A, Chen Y, Kibriya MG, Stavkovich V, Parvez F, Jesmine F, et al. Arsenic metabolism genetic susceptibility and risk of pre malignant skin lesions in Bangladesh. Cancer Epidemiol Biomarkers Prev 2007; 16: 19.

19. Salminen S, Bouley C, Ruanlt MCB, Cummings JH, Frank A, Gibson GR, et al. Functional food science and gastor intestinal physiology and function. Br J Nutr 1998; 80: 147-71. 